\title{
Sloths in the city: unexpectedly high density of pale-throated three-toed sloths (Bradypus tridactylus) found in an urban forest patch in Paramaribo, Suriname
}

\author{
Monique Pool ${ }^{\mathrm{A}}$, Ruby Boateng ${ }^{\mathrm{B}}$, Ann-Marie Ako-Adounvo ${ }^{\mathrm{B}}$, \\ Rachelle Allen-McFarlane ${ }^{B}$, Diana Elizondo ${ }^{B}$, Henri Paturault ${ }^{B}$, Haifa Alhawas ${ }^{B}$ \\ AND GEORGE MIDDENDORF ${ }^{\mathrm{B}, 1}$ \\ ${ }^{A}$ Green Heritage Fund Suriname, Paramaribo, Suriname

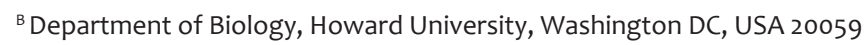 \\ 'Corresponding author. E-mail: gmiddendorf@howard.edu
}

\begin{abstract}
In October 2012 individuals associated with the Green Heritage Fund Suriname organized a rescue of arboreal mammals displaced during deforestation of a 6.8 ha plot in northwest Paramaribo. Rescued or observed animals included 137 pale-throated three-toed sloths (Bradypus tridactylus), eight two-toed sloths (Choloepus didactylus), three Brazilian porcupines (Coendou prehensilis), and three silky anteaters (Cyclopes didactylus). In addition, two lesser anteaters (Tamandua tetradactyla) - a mother and baby - were seen but not rescued. Due to their lack of speed and inability to escape, it is likely that almost all of the pale-throated sloths in the forested plot were captured during the thirty-day period of clear-cutting. Comprising $91 \%$ of the total rescued animals, the 137 B. tridactylus included 61 males, 56 females, 15 juveniles, and five adults that could not be sexed. Data on body mass, length, and other features reveal a population of reasonably healthy but smaller animals at a population density of 20.1 animals / ha that far exceeds any previous reports for this species.
\end{abstract}

Keywords: habitat fragmentation, Pilosa, population density, urban mammal, urbanophilic, Xenarthra

Inesperada alta densidad de perezosos de tres dedos (Bradypus tridactylus) en un parche de bosque urbano en Paramaribo, Suriname

Resumen En octubre de 2012, voluntarios asociados a Green Heritage Fund Suriname organizaron un rescate de mamíferos arbóreos desplazados durante la deforestación de una parcela de 6,8 ha situada al noroeste de Paramaribo. Los animales rescatados incluyeron 137 perezosos de tres dedos (Bradypus tridactylus), ocho perezosos de dos dedos (Choloepus didactylus), tres puercoespines brasileños (Coendou prehensilis) y tres hormigueros sedosos (Cyclopes didactylus). Además fueron vistos dos osos meleros (Tamandua tetradactyla) una madre y su cachorro - aunque no fueron recogidos. Debido a su baja velocidad y su incapacidad para esconderse, es probable que prácticamente todos los animales de la parcela fueran capturados durante el período de tala de 30 días. Bradypus tridactylus representó el $91 \%$ del total de los animales rescatados; de los 137 individuos, 61 eran machos, 56 hembras, 15 juveniles y cinco adultos que no pudieron ser sexados. Los datos colectados sobre peso corporal, longitud y otras características muestran una población de animales razonablemente sanos pero más pequeños, con una densidad poblacional de 20,1 animales/ha que excede con creces a la de cualquier reporte previo de esta especie.

Palabras clave: densidad poblacional, fragmentación de hábitat, mamíferos en áreas urbanas, Pilosa, Xenarthra 


\section{INTRODUCTION}

Although well known for their "slothful" nature, it is only recently that more research has been conducted on aspects of the natural history of three-toed sloths, and in particular the subject of this study, the pale-throated three-toed sloth, Bradypus tridactylus. Of the four extant species of three-toed sloths only two are widely distributed. These are the brownthroated three-toed sloth, B. variegatus (Soares \& Carneiro, 2002; Bezzera et al., 2008; Hayssen, 2010), and the pale-throated three-toed sloth, B. tridactylus (Hayssen, 2009a). The other two species, the maned sloth, B. torquatus (Hayssen, 2009b), and the pygmy sloth, B. pygmaeus (Hayssen, 2008), have very limited distributions. In their reevaluation of the distribution of B. tridactylus and B. variegatus, MoraesBarros et al. (2010) restricted the distribution of the pale-throated three-toed sloth, B. tridactylus, to the Guiana shield region (from middle Venezuela across the coast of the three Guianas to the northern side of the Amazon River; see Fig. 1 in Moraes-Barros et al. 2010).

Because they are generally stationary, freeze in response to loud sounds, avoid predators by moving slowly, and are extremely silent when making rare and careful movements (Chiarello, 2008), sloths are difficult to locate, even when they are gregarious in anthropogenic habitats (Silva et al., 2013). Consequently, studies of the ecology, abundance, and density of $B$. tridactylus are lacking. However, rescue operations may provide the best and most realistic estimates of $B$. tridactylus population density (Laufer et al., 2012), and provide a unique opportunity to inventory, sample, and study species normally hard to observe or capture (Vié, 1998). A rescue effort in Paramaribo, Suriname in October 2012 presented a unique opportunity to collect data on the numbers and demography of palethroated three-toed sloths. Being able to collect all of the individuals present in the study area allowed us to assess demographic and physical attributes of an entire $B$. tridactylus population in an urban, contiguous, relatively undisturbed, and isolated forest patch.

\section{MATERIALS AND MeTHODS}

Between 22 October and 22 November 2012 volunteers associated with the Green Heritage Fund Suriname rescued sloths from the Theo Stolk property, a 6.8 ha forest patch, which was being clear-cut to establish a pasture for cattle. Located in the north of Paramaribo, the capital city of Suriname $\left(5^{\circ} 50^{\prime} \mathrm{N}\right.$, $\left.55^{\circ} 10^{\prime} \mathrm{W}\right)$, the typical coastal swamp forest was surrounded on all sides by recent housing developments and pastureland (FIG. 1). Notable vegetation in

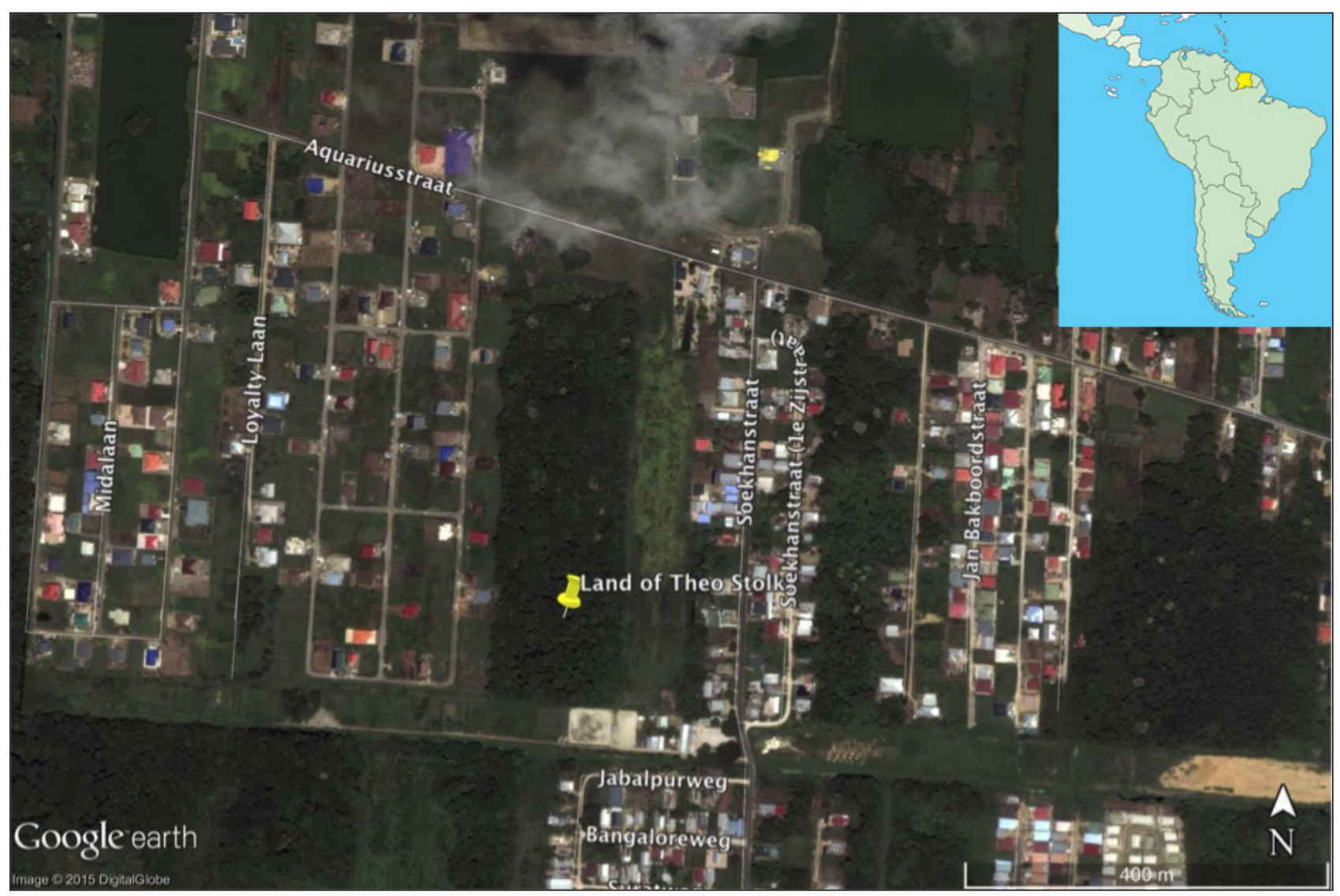

FIGURE 1. Sloths and other arboreal mammals were rescued from a forested plot (Land of Theo Stolk) in Paramaribo, Suriname that was clear-cut in 2012. Surrounding areas are either developed or pastureland. Satellite photo via Google Earth. 
the forest included the trees Hura crepitans, Triplaris surinamensis, and Virola surinamensis, as well as Cecropia spp., found particularly at the forest edges, Inga spp., Ceiba pentandra, and different types of vines, among which Ipomoea spp. dominated.

The patch of forest was cleared using a Caterpillar 215B hydraulic excavator that pushed the trees over. When an animal was spotted, the operator would proceed slowly so that the animal would not be hurt and could be removed by volunteers from the treetop that was now on the ground. The animals were either placed in cloth bags or kennels. Although every effort was made for the safety of the animals, stress was undoubtedly an issue. This was addressed after animals were transported to a temporary holding site. There we recorded the hydration condition of all rescued animals (TABLE 1) and each animal, regardless of condition, was offered water with Rescue Remedy drops (Bach, Thousand Oaks, CA, USA), using pipettes or injection syringes without needles to reduce stress. All rescued animals were given a unique identification code that identified the species, the date, and a sequential number indicating the order in which the animal was rescued that day. Although eight two-toed sloths (Choloepus didactylus), three Brazilian porcupines (Coendou prehensilis), and three silky anteaters (Cyclopes didactylus) were rescued, the only species for which extensive data were recorded was B. tridactylus. Those data are presented and discussed here.

Adult male pale-throated three-toed sloths have a dorsal marking or speculum, as it is called, that consists of an orange-yellow patch combined with a black central streak and sometimes black spots (Beebe, 1926; Anderson \& Handley, 2001; Hayssen, 2009a; M. Pool, pers. obs.). At about one year of age the development of an apparently individually unique speculum allows for differentiation of the sex of individuals (M. Pool, pers. obs.). Prior to this, gender assignment is particularly challenging because of the lack of any sexually dimorphic characteristics (Martinelli et al., 2010). Because the smallest identifiable male in our study weighed $1.3 \mathrm{~kg}$, any animal below that mass was classified as a juvenile and not sexed. Because of uncertainty about the presence of a speculum, two animals that exceeded $1.3 \mathrm{~kg}$ were classified as adults of unknown sex and not included in the demographic analysis.

Animals considered juveniles were weighed using a Plateau digital kitchen scale (Soehnle, Backnang, Germany) while adult body mass was determined using a calibrated analog fishing scale (Salter Model 235, West Bromwich, UK). Animal body length was determined by laying a measuring tape along the spine from the tip of the tail to the tip of the nose. The reported sample sizes vary in the results because we were unable to collect full sets of data for one juvenile, two adults of unknown sex, 15 adult males, and 12 adult females. Although one animal (BT2303) was injured during the clear-cutting, no injuries occurred during the data collection process. Two animals (one male and one unidentified) were found dead at the end of the rescue effort; we noted their presence in the population but did not record other measurements. Each animal was photographed with its unique identification code to provide a complete record of all animals rescued (135) or found dead (2). Pictures taken, either during data collection or upon release, included at least one frontal face picture, one side face picture and one dorsal picture of the complete animal.

Because of the numbers of animals that had to be quickly processed and because of the lack of experience of many volunteers, we were unable to take measurements from all animals and limited the number of body-size measurements to a set that could be rapidly and accurately measured. Skull size was determined using calipers to measure width from ear to ear. Thorax width was measured on the dorsal side of the sloth; the arms of the animal were slightly lifted so that the calipers could be placed from armpit to armpit. The fore palm length of one arm was measured from Carpal I to the inset of the nails. Finally, the back palm of one leg was measured from the posterior edge of the heel bone to the inset of the nails. Because of handling difficulties, we did not attempt to ensure that an equal number of the latter two measurements were measured on the right and left sides. Recorded data sets were transcribed and entered into an Excel (Microsoft

TABLE 1. Determination of hydration condition. Hydration condition was assessed by checking the animal's tongue, nose, and eyes, as well as whether it was willing to drink.

\begin{tabular}{ll}
\hline Descriptor & Definition \\
\hline Hydrated & Skin on nose looks smooth, healthy and warm, and has a dark black shiny color. \\
& Eyes are clear and edges of eyelids are smooth. Mouth is hydrated and tongue is wet. \\
& Skin on nose looks smooth with thin white cracks in the black skin, which pulls on the edges. Eyes are clear \\
and edges of eyelids are slightly cracked and dirty. & Mouth is hydrated and tongue is wet. \\
Slightly dehydrated & $\begin{array}{l}\text { Skin on nose looks dry and is cracked, and black skin has whitish appearance. Skin pulls at the edges. Eyes } \\
\text { covered in whitish film. }\end{array}$ \\
\hline
\end{tabular}


Corporation, Redmond, USA) spreadsheet for analysis. Significance for statistical tests using chi-square and $\mathrm{t}$ - tests was determined at the $\mathrm{p}=0.05$ level.

Urbani \& Bosque (2006) proposed a standardized framework (updated by Silva et al., 2013) for categorizing the behavior of sloths in their natural habitat. Because we recorded behaviors during the wildlife rescue operation as animals were handled and measured, our behavioral categories are not directly comparable. Based on extensive experience with sloth behavior in rescue situations, animal reactions to capture and handling were recorded prior to and during handling, but not afterwards when animals were housed together until release (approximately two to three days for healthy animals). The behavior of each animal was categorized as calm, restless, afraid, or aggressive. Calm corresponded to normal behavior, in which a sloth did not show any signs of agitation and would just sit calmly looking around in a stationary, resting position (similar to the huddle position used by Urbani \& Bosque, 2006; Silva et al., 2013). Restless was assigned to animals moving around in the cage, observing the surrounding area, or trying to stick either forearms or head through the cage in an apparent attempt to escape. Animals categorized as afraid moved away from handlers, ducked their heads in between their forearms, or wailed. Aggressive animals tried to hook, bite, huffed or blew at handlers.

\section{RESULTS}

Of the 135 rescued and two deceased palethroated three-toed sloths (B. tridactylus), 61 were males, 56 females, 15 juveniles, and five adults of unknown sex. Only one mother - offspring pair was captured. All remaining juveniles were found alone. Overall population density of the pale-throated three-toed sloths at the site was 20.1 animals/ha, comprised of 7.0 males/ha, 8.2 females/ha, and 2.2 juveniles/ha. The ratio of males to females, 1.09:1 $(\mathrm{N}=117)$, was not significantly different from 1:1 $\left(\mathrm{X}^{2}=0.21, \mathrm{df}=1, \mathrm{p}=0.644\right)$.

Average adult female body mass was significantly greater than that of adult males $(t=2.06, d f=88$, $\mathrm{p}=0.042 ;$ TABLE 2). Average adult body mass was more than three times that of juveniles (TABLE 2). Female body length was also significantly greater than that of adult males ( $\mathrm{t}=2.16, \mathrm{df}=89, \mathrm{p}=0.034$; TABLE 2$)$, and both females and males were larger than juveniles (TABLE 2). The relationship of body mass to body length did not appear to differ between males and females (FIG. 2).

Adult females did not differ significantly from adult males in the size of the skull $(t=0.39, \mathrm{df}=97$, $\mathrm{p}=0.69)$, thorax $(\mathrm{t}=0.46, \mathrm{df}=80, \mathrm{p}=0.64)$, fore palm $(\mathrm{t}=0.09, \mathrm{df}=87, \mathrm{p}=0.36)$, or back palm $(\mathrm{t}=0.22, \mathrm{df}=97$, $\mathrm{p}=0.83$; see TABLE 3).

For two-thirds of the animals (72) hydration condition was considered good; 14 were reported as slightly dehydrated, and 18 as dehydrated. No data on hydration were collected for 26 animals that were only photographed and not measured, as well as for three others.

Of the 108 behaviorally assessed sloths, almost two thirds were calm upon capture $(68 ; 31$ males, 26 females, 10 juveniles, 1 unknown). Of the remaining,

TABLE 2. Body mass and length of rescued pale-throated three-toed sloths, Bradypus tridactylus, by sex and age (Mean \pm sd and range are shown). Data were not recorded for all rescued animals.

\begin{tabular}{lccccc}
\hline & \multicolumn{2}{c}{ Mass $(\mathrm{kg})$} & Mean $(\mathrm{sd})$ & Rength $(\mathrm{cm})$ \\
\hline Male & $\mathrm{N}$ & Mean $(\mathrm{sd})$ & Range & $56.40(4.33)$ & $44.5-65.0$ \\
Female & 46 & $3.23(0.68)$ & $1.30-4.80$ & $58.23(3.70)$ & $49.5-66.0$ \\
Juvenile & 44 & $3.52(0.65)$ & $2.20-4.95$ & $36.35(3.06)$ & $30.5-40.5$ \\
Unknown & 15 & $0.98(0.32)$ & $0.55-1.87$ & $55.75(6.72)$ & $51.0-60.5$ \\
\hline
\end{tabular}

TABLE 3. Mean, standard deviation (sd), and minimum and maximum size of skull, thorax, fore palm and back palm ( $\mathrm{cm}$ ) of rescued pale-throated three-toed sloths, Bradypus tridactylus, by sex and age. Data were not recorded for all rescued animals as well as for the fore and back palm for one rescued female and one rescued male.

\begin{tabular}{lccccccccc}
\hline & \multicolumn{4}{c}{ Skull } & \multicolumn{2}{c}{ Thorax } & \multicolumn{2}{c}{ Fore palm } & \multicolumn{2}{c}{ Back palm } \\
\hline & $\mathrm{N}$ & Mean $(\mathrm{sd})$ & Range & Mean $(\mathrm{sd})$ & Range & Mean $(\mathrm{sd})$ & Range & Mean $(\mathrm{sd})$ & Range \\
\hline Male & 46 & $4.54(0.30)$ & $3.7-5.4$ & $8.31(0.95)$ & $5.6-10.6$ & $6.80(0.88)$ & $4.9-8.7$ & $8.76(0.94)$ & $6.0-10.2$ \\
Female & 43 & $4.58(0.37)$ & $4.0-5.7$ & $8.44(0.71)$ & $7.0-9.5$ & $6.91(0.63)$ & $5.5-8.0$ & $8.97(0.90)$ & $6.5-10.5$ \\
Juvenile & 15 & $3.49(0.33)$ & $3.0-4.2$ & $4.79(0.71)$ & $3.5-6.2$ & $3.91(0.82)$ & $3.0-6.0$ & $5.71(0.73)$ & $4.5-7.0$ \\
Unknown & 2 & $4.45(0.07)$ & $4.4-4.5$ & $8.40(1.13)$ & $7.6-9.2$ & $6.00(0.71)$ & $5.5-6.5$ & $6.75(1.06)$ & $6.0-7.5$ \\
\hline
\end{tabular}




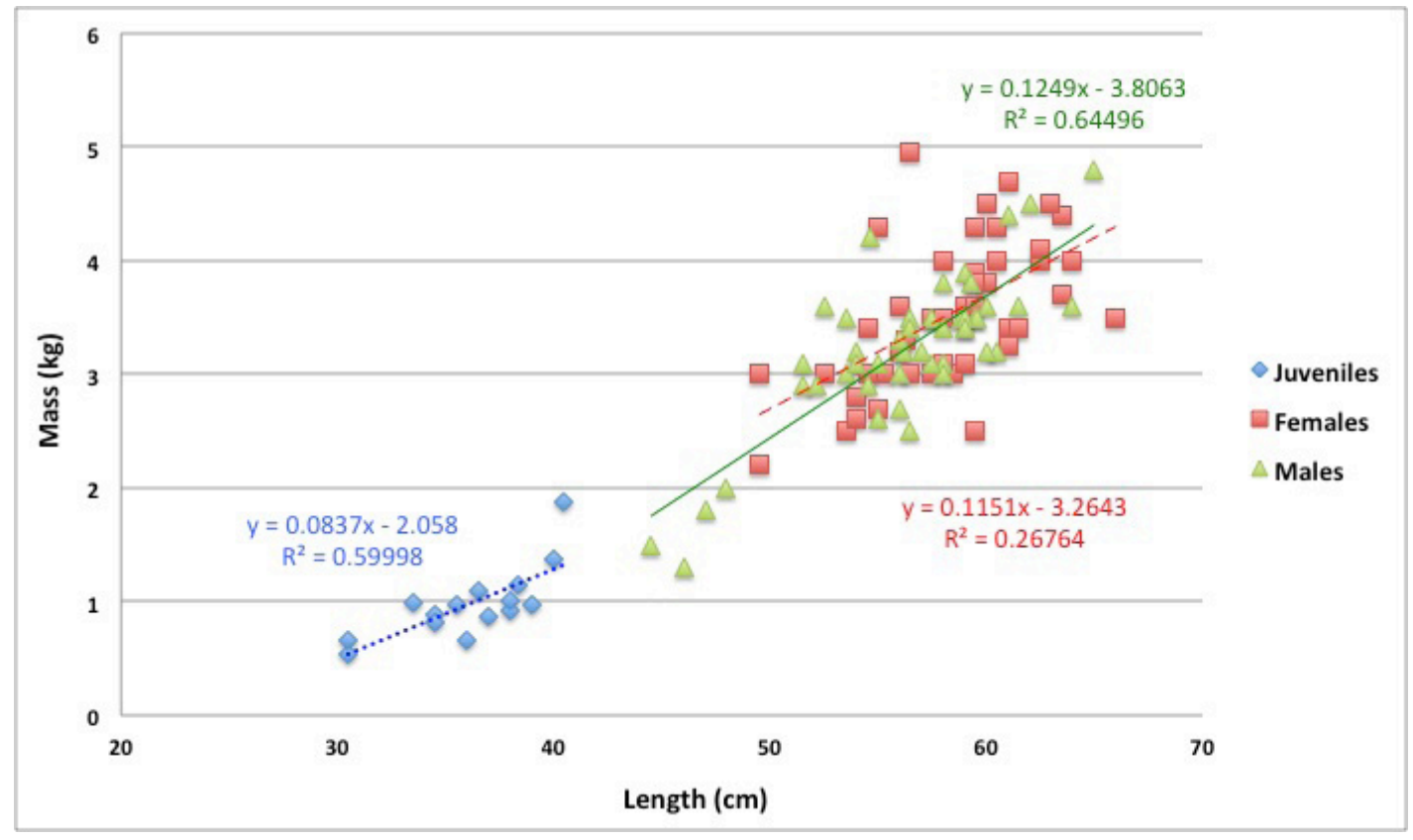

FIGURE 2. Body length by mass correlations for pale-throated three-toed sloths, Bradypus tridactylus, by sex and age.

six were categorized as restless ( 2 males, 4 females, 0 juveniles), 17 as afraid ( 7 males, 7 females, 2 juveniles, 1 unknown), and 17 as aggressive ( 7 males, 7 females, 3 juveniles). Behavioral assessment of males $(\mathrm{N}=47)$ and females $(\mathrm{N}=44)$ was not significantly different $\left(X^{2}=1.01, d f=3, p=0.799\right)$. Because of small sample size, juveniles could not be compared.

\section{DISCUSSION}

Studies reporting abundance and density estimates of $B$. tridactylus are scarce, perhaps because stationary sloths are hard to detect in the forest canopy (Laufer et al., 2012), even by trained observers (Chiarello, 2008). Our estimate of 20.1 animals/ha represents the greatest documented population density of this species. The highest densities previously reported were 12.7 animals/ha (Réus \& Martins de Souza, 2007) and 2.2 animals/ha (Carmo, 2002), both for urban populations in Manaus, Brazil. Other estimates are considerably lower (TABLE 4). For example, a rescue operation during the filling of the Petit Saut dam yielded 0.02 animals/ha along the Sinnamary River in French Guiana (Taube et al., 1999). Unfortunately, because juveniles and their mothers were recorded as single individuals, and because the number of maternal-offspring pairs was not provided, exact comparison with our data is not possible. However, recalculation of our data to match Taube et al.'s (1999) methodology by "pairing" juveniles with females yields an estimate of 108 animals and a density of 17.9 animals / ha - still orders of magnitude higher. Taube et al.'s (1999) comment that approximately $23-24 \%$ of both B. tridactylus and C. didactylus were females carrying young does not substantially affect the density.

Other studies provide density estimates that are similarly low. For instance, a non-rescue study in Guyana by Beebe (1926) reported a density of 0.3 animals/ha. The results of the Conservation International Rapid Biological Assessment in southern Suriname (Gajapersad et al., 2011) did not include any mention of sloths-a surprising absence given that the mammal surveys included a variety of methods, e.g., camera traps, scat, and animal track searches, and visual and aural observations. Laufer et al. (2012) reported a density of 0.002 animals/ $\mathrm{km}$ along three rivers in the northern Amazonia of Brazil near French Guiana. Although river transect methodology may not be directly comparable, if we generously allow a $100 \mathrm{~m}$ visual field along the river's edge, the results translate to densities of 2 animals/ha. A perhaps more realistic visual field of $10 \mathrm{~m}$ would result in a much lower density of 0.2 animals/ha. Population densities for the closely-related brown-throated three-toed sloth, B. variegatus, range from 0.0001 animals/ha (applying the same translation to the river transect date of Haugaasen \& Peres, 2005) to 26 animals / ha (TABLE 4). Interestingly, densities for both $B$. tridactylus and $B$. variegatus were higher in urban areas than in natural habitats (TABLE 4).

Laufer et al. (2012) argued that wildlife rescue operations will always provide a better estimate of sloth density because the majority of animals are seen 
TABLE 4. Summary of studies with population density estimates (individuals/ha) for Bradypus tridactylus and B. variegatus for a variety of field methodologies and habitats. * Density estimated from linear conversion; see text for details.

\begin{tabular}{|c|c|c|c|}
\hline Species/Location & $\begin{array}{l}\text { Density } \\
\text { (ind/ha) }\end{array}$ & Method/habitat & Reference \\
\hline \multicolumn{4}{|l|}{ B. tridactylus } \\
\hline $\begin{array}{l}\text { Kwamalasamutu Region, Southwestern } \\
\text { Suriname }\end{array}$ & 0 & $\begin{array}{l}\text { Rapid Biological Assessment/ Lowland } \\
\text { rainforest }\end{array}$ & Gajapersad et al. (2011) \\
\hline Petit Saut dam, French Guiana & 0.02 & Rescue/ Primary lowland rainforest & Taube et al. (1999) \\
\hline $\begin{array}{l}\text { Floresta Nacional do Amapá (FLONA), } \\
\text { Northern Amazonia, Brazil }\end{array}$ & $0.2^{*}$ & River transect/ Rainforest & Laufer et al. (2012) \\
\hline Kartabo, Bartica District, Guyana & 0.3 & Observations/ Lowland rainforest & Beebe (1926) \\
\hline $\begin{array}{l}\text { Universidade Federal do Amazonas, } \\
\text { Manaus, Brazil }\end{array}$ & 2.2 & Grid/Urban forest fragment & $\begin{array}{l}\text { Carmo (2002; cited in Réus \& } \\
\text { Martins de Souza, 2007) }\end{array}$ \\
\hline Bosque da Ciência, Manaus, Brazil & 12.7 & Transect/Urban forest fragment & Réus \& Martins de Souza (2007) \\
\hline Paramaribo, Suriname & 20.1 & $\begin{array}{l}\text { Rescue/ Urban coastal swamp forest } \\
\text { fragment }\end{array}$ & This study \\
\hline \multicolumn{4}{|l|}{ B. variegatus } \\
\hline Rio Puru, Brazilian Amazonia & $0.0001^{*}$ & $\begin{array}{l}\text { River transect/ Terra firme and varzea } \\
\text { forests }\end{array}$ & Haugaasen \& Peres (2005) \\
\hline Gorgona Island, Colombia & 0.026 & Transect/Rainforest & Garcés-Restrepo et al. (2014) \\
\hline Arboletes, Antioquia, Colombia & $0.6-4.5$ & Transect/Tropical dry forest & Acevedo-Quintero et al. (2011) \\
\hline Isla Palma, Valle, Colombia & 0.7 & Transect/Rainforest & Carvajal-Nieto et al. (2013) \\
\hline $\begin{array}{l}\text { Mamirauá Ecological Station, Ama- } \\
\text { zonas, Brazil }\end{array}$ & $2.2-6.7$ & Transect/Rainforest & $\begin{array}{l}\text { Queiroz (1995; cited in Mo- } \\
\text { raes-Barros et al., 2014) }\end{array}$ \\
\hline Barro Colorado Island, Panama & 8.5 & $\begin{array}{l}\text { Observations/ } \\
\text { Lowland rainforest }\end{array}$ & Montgomery \& Sunquist (1975) \\
\hline $\begin{array}{l}\text { Praça Tiradentes, Teófilo Otoni City, } \\
\text { Minas Gerais, Brazil }\end{array}$ & $10-12$ & All animals identified/Urban park & $\begin{array}{l}\text { Manchester \& Jorge (2009); } \\
\text { Queiroz et al. (2015) }\end{array}$ \\
\hline $\begin{array}{l}\text { Botanic Garden Benjamin Maranhão, } \\
\text { Paraiba, Brazil }\end{array}$ & 26 & Observations/Urban forest fragment & Silva et al. (2013) \\
\hline
\end{tabular}

and rescued, whereas the cryptic nature of sloths will likely result in underestimates of density under natural conditions. Similarly, Núñez-Regueiro et al.'s (2015) report on detection issues for large, more mobile, and presumably less cryptic mammals in mixed forest-agricultural areas in Argentina further underscores the problem of accurately estimating population density. In our study, the unique opportunity offered by the animal rescue effort to determine the density of the $B$. tridactylus population by capturing or observing virtually every animal present might, by itself, have resulted in the "higher than normal" estimate. If so, then perhaps earlier studies simply missed large numbers of these extraordinarily cryptic animals (Chiarello, 2008; Voirin et al., 2009) or perhaps the paucity of comprehensive field studies just did not include such an aggregated population. Regardless, our results suggest that past studies may have substantially underestimated pale-throated three-toed sloth population densities. If true, then the present study in Paramaribo may provide a much more realistic estimation of sloth densities than those previously published. However, we cannot discount several alternative possibilities that alone or together might have generated this high population density, especially given similarly high densities observed in other urban areas (Réus \& Martins de Souza, 2007; Manchester \& Jorge, 2009; Silva et al., 2013; Queiroz et al., 2015).

First, it is possible that historical clear-cutting of the surrounding region may have provided opportunities for the establishment of early successional plant species like Cecropia and sweet potato vines (Ipomoea spp.) - both of which were seen on the site. The presence of these preferred food species of palethroated three-toed sloths could provide greater than normal food resources and, in turn, lead to higher than normal densities (Réus \& Martins de Souza, 2007). However, we noted that the site was mostly an intact swamp forest with Cecropia located only along the edges. Thus, Cecropia was neither abundant in the forest interior nor more abundant than usual in the surrounding areas. We also noted that individuals of this population were slightly smaller than those observed elsewhere, suggesting the possibility of limited food. 
A second possibility is that the lack of predators in this "urban" location, e.g., harpy eagles, arboreal cats, large snakes, etc. might allow for a substantial increase in population size (Réus \& Martins de Souza, 2007). While this hypothesis may be possible, the loss of natural predators could be offset by an increase in non-natural predators (Grant et al., 2011). More data are needed to resolve this issue.

Third, density may be linked to rates of encounters and matings between males and females. Thus, higher density may foster population growth, especially in the absence of limiting resources or predators (Réus \& Martins de Souza, 2007). The fact that the population at Paramaribo was comprised of slightly smaller, perhaps younger, individuals could support this. However, demographic data, including growth rates, encounter rates, mating success, and population density, are needed to determine whether animals are smaller because of age or resource limitation.

Fourth, high density may have resulted from contraction and migration of animals from surrounding areas-an artifact of urbanization collapsing a more dispersed and less dense sloth population inward to the only remaining forested refuge. The forested areas immediately east and west of the Stolk property were clear-cut between 2004 and 2009. It is certainly plausible that animals moved into the remaining undisturbed forest and survived until the present study.

It is also possible that all of these factors could operate together. Thus, sloth densities in the wild may be much higher than previously recorded, and urbanization processes may have the potential to artificially increase them further. Regardless of the causal factor(s), the density of this sloth population is orders of magnitude higher than previously reported for this species, suggesting that sloths may be an interesting and important component of tropical urban landscapes. Indeed, given their densities in urban areas (TABLE 4), sloths may well be considered a tropical, urbanophilic species (Grant et al., 2011). The existence of this high population density of $B$. tridactylus in an urban forest strongly affirms the need to recognize that the establishment of green spaces in cities in the tropics is likely to encourage species conservation. Further investigations are warranted.

The 1.09:1 sex ratio at Paramaribo is similar to that reported by Hayssen (2009a) and Jorge et al. (1985). We found adult males to be smaller than adult females, also as others have reported (Beebe, 1926; Richard-Hansen et al., 1999; Hayssen, 2009a). However, both males and females were smaller at our study site than those reported from elsewhere. For example, Wetzel (1985) reported weights of 3.93 $\mathrm{kg}$ for males and $4.62 \mathrm{~kg}$ for females, both of which are higher than our observations of 3.23 and $3.52 \mathrm{~kg}$, respectively. This difference may be a function of better sampling in our study, with more individuals measured, but could result from reduced availability of resources (food, space, etc.) at high density, or a difference in age structure such that our population consisted of more young individuals. Another reason for greater female body mass could also be pregnancy. Because of injury, one female that had to remain for a longer period at the shelter was found to be pregnant when she miscarried at the end of December. However, we were unable to determine the reproductive status for any of the other females. Similarly, like mass, body length and skull size of Paramaribo pale-throated three-toed sloths were generally less than that reported for other populations. Again, these differences could be either age or nutrition related.

Males, when they can see one another, are often aggressive (Greene, 1989). Likewise, females with young tend to be aggressive and protective when sharing the same tree (Soares \& Carneiro, 2002). The fact that we did not observe differences in the behaviors of newly-captive males and females could reflect similarities in their natural behavioral profiles, but it could also be a result of disturbance due to clear-cutting of the forest. Thus, clear-cutting, followed by collection, may have resulted in behavior not typically observed in the wild. While Silva et al. (2013) utilized a similar framework to ours, we are hesitant to compare their wild and our captive animals because they studied $B$. variegatus. Use of our framework to assess the behavior of B. tridactylus in wildlife rescue situations may aid in assessing individual captive animal responses to disturbance and to interaction with humans, thereby providing a means to evaluate the animal's suitability with respect to translocation in the short or medium term, and improving subsequent survival at the new site.

\section{ACKNOWLEDGEMENTS}

We thank all the many GHFS volunteers for their obvious effort and dedication to this sloth rescue project, but also for their long-standing and largely unrecognized efforts to promote conservation and preservation throughout Suriname. We also thank Natuurbeheer for permission to work with the animals (Suriname Forest Service - Nature Conservation Division Permit 10593).

\section{REFERENCES}

Acevedo-Quintero, J. F., D. P. Sánchez \& T. Plese. 2011. Abundancia y preferencia de hábitat de Bradypus variegatus y Choloepus hoffmanni durante la época seca en dos fragmentos de bosque seco en Arboletes, Antioquia, Colombia. Edentata 12: 36-44. https: / / doi.org/10.5537 / 020.012.0106 
Anderson, R. \& C. Handley. 2001. A new species of three-toed sloth (Mammalia: Xenarthra) from Panamá, with a review of the genus Bradypus. Proceedings of the Biological Society of Washington 114: 1-33.

Beebe, W. 1926. The three-toed sloth Bradypus cucullinger cucullinger Wagler. Zoologica 7: 1-67.

Bezerra, B., S. Antonio, H. Lewis \& S. Nicola. 2008. Observation of brown-throated three-toed sloths: mating behavior and the simultaneous nurturing of two young, brown-throated sloths (Bradypodidae). Journal of Ethology 26: 175-178. https: / / doi.org/10.1007/s10164-007-0038-z

Carmo, N. A. S. 2002. Distribuição, densidade e padrão deatividades de B. tridactylus (Mammalia, Xenarthra) em fragmento florestal na Amazônia Central. Dissertação, Universidade Federal do Amazonas, Manaus.

Carvajal-Nieto, P., A. Giraldo \& T. Plese. 2013. Densidad poblacional y algunos aspectos de uso de hábitat del perezoso de tres dedos (Bradypus variegatus) en un ambiente insular del Chocó bioeográfico Colombiano. Boletín Científico, Centro de Museos, Museo de Historia Natural 17: 101-110.

Chiarello, A. G. 2008. Sloth ecology: an overview of field studies. Pp. 269-280 in: The biology of the Xenarthra (S. F. Vizcaíno \& W. J. Loughry, eds.). University Press of Florida, Gainesville.

Gajapersad, K., A. Mackintosh, A. Benitez \& E. Payán. 2011. A survey of the large mammal fauna of the Kwamalasamutu region, Suriname. Pp. 150-156 in: A rapid biological assessment of the Kwamalasamutu region, southwestern Suriname (B. J. O'Shea, L. E. Alonso \& T. H. Larsen, eds.). RAP Bulletin of Biological Assessment 63. Conservation International, Arlington, VA.

Garcés-Restrepo, M. F., P. Carvajal-Nieto, J. M. Astorquiza, E. Sánchez-Vélez \& A. Giraldo. 2014. Density and structure of populations of Cebus capucinus curtus (Primates: Cebidae) and Bradypus variegatus gorgon (Pilosa: Bradypodidae) in Gorgona Island, Colombia. Revista de Biología Tropical 62: 447-456. https: / / doi.org/10.15517/ rbt.v62i0.16371

Grant, B. W., G. Middendorf, M. J. Colgan, H. Ahmad \& M. B. Vogel. 2011. Ecology of urban amphibians and reptiles: urbanophiles, urbanophobes, and the urbanoblivious. Pp. 167-178 in: Urban ecology: patterns, processes, and applications (J. Niemelä, J. H. Breuste, T. Elmqvist, G. Guntenspergen, P. James \& N. E. McIntyre, eds.). Oxford University Press, Oxford. https://doi.org/10.1093/ acprof:oso/9780199563562.003.0020
Greene, H. W. 1989. Agonistic behavior by threetoed sloths, Bradypus variegatus. Biotropica 21: 369-372. https: / / doi.org/10.2307 / 2388289

Haugaasen, T. \& C. A. Peres. 2005. Primate assemblage structure in Amazonian flooded and unflooded forests. American Journal of Primatology 67: 243-258. https://doi. org / 10.1002 / ajp.20180

Hayssen, V. 2008. Bradypus pygmaeus (Pilosa: Bradypodidae). Mammalian Species 812: 1-4. https: / doi.org / 10.1644/812.1

Hayssen, V. 2009a. Bradypus tridactylus (Pilosa: Bradypodidae). Mammalian Species 839: 1-9. https: / / doi.org/10.1644/839.1

Hayssen, V. 2009b. Bradypus torquatus (Pilosa: Bradypodidae). Mammalian Species 829: 1-5. https: / / doi.org/10.1644/829.1

Hayssen, V. 2010. Bradypus variegatus (Pilosa: Bradypodidae). Mammalian Species 42(850): 19-32. https: / / doi.org/10.1644/850.1

Jorge, W., A. T. Orsi-Souza \& R. Best. 1985. The somatic chromosomes of Xenarthra. Pp. 121-129 in: The evolution and ecology of armadillos, sloths, and vermilinguas (G. G. Montgomery, ed.). Smithsonian Institution, Washington and London.

Laufer, J., J. A. Amador, P. C. Conceição, D. Norris \& F. Michalski. 2012. Use of boat surveys to provide complementary data on the ecology of Bradypus tridactylus (Pilosa: Bradypodidae) from Northern Amazonia. Edentata 13: 56-60. https: / / doi.org / 10.5537 / 020.013.0115

Manchester, A. \& W. Jorge. 2009. Biological data of a population of sloths (Bradypus variegatus) in a square of Teófilo Otoni, Minas Gerais, Brazil. Naturalia 32: 81-86.

Martinelli, A. B., N. de Moraes-Barros, C. S. Alvarenga, P. B. Chaves, L. A. Santos \& V. Fagundes. 2010. A PCR-RFLP assay for gender assignment in the three-toed sloths (Bradypus, Pilosa, Bradypodidae). Molecular Ecology Resources 10: 732-734. https://doi. org/10.1111/j.1755-0998.2009.02820.x

Montgomery, G. G. \& M. E. Sunquist. 1975. Impact of sloths on Neotropical forest energy flow and nutrient cycling. Pp. 69-98 in: Tropical ecological systems: trends in terrestrial and aquatic research (F. B. Golley \& E. Medina, eds.). Springer-Verlag, Berlin. https://doi. org / 10.1007 / 978-3-642-88533-4_7

Moraes-Barros, N., A. Chiarello \& T. Plese. 2014. Bradypus variegatus. The IUCN Red List of Threatened Species 2014: e.T3038A47437046. <http:/ / dx.doi.org/10.2305/IUCN.UK.2014-1. 
RLTS.T3038A47437046.en>. Accessed 2 December 2016.

Moraes-Barros, N., A. P. Giorgi, S. Silva \& J. Stenghel Morgante. 2010. Reevaluation of the geographical distribution of Bradypus tridactylus Linnaeus, 1758 and B. variegatus Schinz, 1825. Edentata 11: 53-61. https: / / doi.org/10.1896/020.011.0110

Núñez-Regueiro, M. M., L. Branch, R. J. Fletcher Jr., G. A. Marás, E. Derlindati \& A. Tálamo. 2015. Spatial patterns of mammal occurrence in forest strips surrounded by agricultural crops of the Chaco region, Argentina. Biological Conservation 187: 19-26.

Queiroz, H. L. de. 1995. Preguiças e Guaribas: os mamíferos folívoros arborícolas do Mamirauá. Conselho Nacional de Desenvolvimento Cientifico e Tecnológico e Sociedade Civil Mamirauá, Brasília e Tefé, Brazil. 160 pp.

Queiroz, C. S., B. K. C. Santos, A. M. P. M. Goncalves, J. R. Lisboa \& C. A. Bomfeti. 2015. Hematologia de preguiças de três dedos Bradypus variegatus (Bradypodidae, Xenarthra) da praça Tiradentes em Teófilo Otoni. Revista Vozes dos Vales 8: $1-11$.

Réus, C. L. \& C. Martins de Souza. 2007. Estructura populacional de Bradypus tridactylus (Xenarthra, Bradypodidae) em fragmento florestal urbano no município de Manaus, Amazonas, Brasil. Estudos de Biologia: Ambiente e Diversidade 29: 249-256.

Richard-Hansen, C., J-C. Vié, N. Vidal \& J. Keravec. 1999. Body measurements on 40 species of mammals from French Guiana. Journal of Zoology 247: 419-428. https://doi. org/10.1111/j.1469-7998.1999.tb01005.x

Silva, S. M., C. L. Clozato, N. Moraes-Barros \& J. S. Morgante. 2013. Towards a standard framework to describe behaviours in the common-sloth (Bradypus variegatus Schinz, 1825): novel interactions data observed in distinct fragments of the Atlantic forest, Brazil. Brazilian Journal of
Biology 73: 527-531. https://doi.org/10.1590/ S1519-69842013000300010

Soares, C. \& R. Carneiro. 2002. Social behavior between mothers $x$ young of sloths Bradypus variegatus Schinz, 1825 (Xenarthra: Bradypodidae). Brazilian Journal of Biology 62: 249-252. https: / / doi.org/10.1590/S1519-69842002000200008

Taube, E., J-C. Vié, P. Fournier, C. Genty \& J-M. Duplantier. 1999. Distribution of two sympatric species of sloths (Choloepus didactylus and Bradypus tridactylus) along the Sinnamary River, French Guiana. Biotropica 31: 686-691. https: / / doi.org/10.1111/j.1744-7429.1999.tb00418.x

Urbani, B \& C. Bosque. 2006. Feeding ecology and postural behaviour of the three-toed sloth (Bradypus variegatus flaccidus) in northern Venezuela. Mammalian Biology 72: 321-329. https: / / doi.org/10.1016/j.mambio.2006.10.013

Vié, J-C. 1998. La translocation de la faune sauvage de Petit Saut: apport pour la connaissance scientifique et la conservation de la nature en Guyane. Journal d'Agriculture Traditionnelle et de Botanique Appliquée 40: 465-484. https:// doi.org/10.3406/jatba.1998.3686

Voirin, J. B., R. Kays, M. D. Lowman \& M. Wikelski. 2009. Evidence for three-toed sloth (Bradypus variegatus) predation by spectacled owl (Pulsatrix perspicillata). Edentata 8-10: 15-20. https: / doi.org/10.1896/020.010.0113

Wetzel, R. 1985. The identification and distribution of recent Xenarthra (= Edentata). Pp. 5-21 in: The evolution and ecology of armadillos, sloths, and vermilinguas (G. G. Montgomery, ed.), Smithsonian Institution Press, Washington and London.

Received: 12 May 2015; Accepted: 10 December 2016 